\title{
Von Willebrand disease type 3
}

INSERM

\section{Source}

INSERM. (1999). Orphanet: an online rare disease and orphan drug data base. Von

Willebrand disease type 3. ORPHA:166096

Type 3 von Willebrand disease (type 3 VWD) is the most severe form of VWD (see this term) characterized by a bleeding disorder associated with a total or near-total absence of Willebrand factor (von Willebrand factor; VWF) in the plasma and cellular compartments, also leading to a profound deficiency of plasmatic factor VIII (FVIII). 